\section{Stunting: its relation to overweight, global or localized adiposity and risk factors for chronic non-communicable diseases}

\section{Deficit estatural: relações com sobrepeso, adiposidade global ou localizada e fatores de risco para doenças crônicas não- transmissíveis}

Valéria Cristina Ribeiro Vieira ${ }^{1}$

Sylvia do Carmo Castro Fransceschini ${ }^{2}$

Mauro Fisberg ${ }^{3}$

Sílvia Eloiza Priore ${ }^{4}$

1 Departamento de Nutrição. Universidade Federal de Alfenas. Rua Gabriel Monteiro da Silva, 714. Centro. Alfenas, MG, Brasil. CEP: 37.130-000 E-mail: valnut@unifal-mg.edu.br

2,4 Departamento de Nutrição e Saúde. Universidade Federal de Viçosa. Viçosa, MG, Brasil.

3 Departamento de Pediatria. Centro de Atendimento e Apoio ao Adolescente. Escola Paulista de Medicina. Universidade Federal de São Paulo. São Paulo, SP, Brasil.

\begin{abstract}
This article discloses and discusses recent findings that have associated stunting - which still represents the most prevalent deviation from normal body measurements among children living in developing countries with overweight and higher adiposity, mainly in the central region of the body, and their clinical and physio-pathological consequences. Although there is need for further studies to clarify these associations, there is a tendency for the weight/height index and body fat topography to behave differently in short and normal stature individuals, mainly in females. This review, therefore, alerts health professionals this characteristic, given that this anthropometric profile may be linked to the widespread occurrence of chronic noncommunicable diseases and/or to risk factors for these conditions and that stunting is still a reality in developing countries.
\end{abstract}

Key words Body height, Overweight, Adiposity, Waist-hip ratio

\section{Resumo}

O presente artigo tem como objetivos apresentar e discutir os recentes achados que associam o deficit estatural - que ainda representa o desvio antropométrico mais prevalente em crianças de países em desenvolvimento - ao sobrepeso, e a maior adiposidade, sobretudo a localizada na região central do corpo, e suas conseqüências clínicas e fisiopatológicas. Apesar da necessidade de mais estudos para esclarecer essas associações, há uma tendência para comportamentos diferentes dos índices de peso relativo à estatura e da topografia da gordura corporal nos indivíduos de baixa estatura e de estatura normal, fato observado especialmente naqueles do sexo feminino. Assim, esta revisão alerta os profissionais de saúde para estarem atentos a tal característica, considerando-se que o perfil antropométrico especificado pode estar ligado a maior ocorrência de doenças crônicas não-transmissíveis elou a seus fatores de risco, e que o deficit estatural ainda é uma realidade nos países em desenvolvimento.

Palavras-chave Estatura, Sobrepeso, Adiposidade, Relação cintura-quadril 


\section{Introduction}

\section{Is stunting still a public health problem?}

The height/age index reflects the linear growth achieved during the pre- and post-natal periods. In demographic terms, it can be used as an indicator of the socio-economic status of a social group or a country, as a deficit for this index is normally the result of a prolonged period of ill-health, malnutrition or both. ${ }^{1}$ As it is derives from a cumulative process of deficient growth that is not easily reversible and that occurs principally before the age of three years, retarded linear growth is taken to a good "synthesis indicator" of the living conditions of a population. ${ }^{2-4}$

The Word Health Organization (WHO) ${ }^{1}$ proposes a classification of low stature or stunting when the height for age lies below the third percentile or $-2 \mathrm{Z}$ scores, in relation to the National Center for Health Statistics (NCHS) distribution. The Center for Diseases Control and Prevention (CDC), in its review of the NCHS curves, ${ }^{5}$ which extends the graphs up to 20 years of age, proposes a cut-off point for low stature in children and adolescents at the fifth percentile.

It is believed that the processes that lead to stunting occur in the pre- and post-natal periods, and that their causes are commonly related to insufficient ingestion of macro- and micronutrients, infections, interactions with the carer, and hereditary factors. ${ }^{6-8}$

In developing countries, post-natal growth retardation commonly begins between three and six months after birth. ${ }^{6,9}$ Children at the start of their life have somewhat greater nutritional needs owing to the rapid pace of their growth. At the same time, they have relatively little gastric capacity, and therefore need frequent meals and high concentrations of energy and nutrients. Poor nutrition weakens an immune system that is not yet mature, altering its susceptibility to infections and contributing to a higher frequency of admission to hospital, which is also influenced by high exposure to infectious agents and the absence of breastfeeding. ${ }^{10}$ Infectious diseases, in turn, make it difficult for the body to absorb nutrients properly and limit the pace of growth and the maturing of bones. The effect of this so-called "malnutrition-infection cycle" in terms of growth retardation in the first years of life is estimated to lie between 10 and $80 \% .^{11}$ These factors, in addition to the complete dependency on others, and, frequently, intra-uterine growth retardation, contribute to the fact that, in developing countries, the incidence of malnutrition reaches a peak and is at its most severe at the beginning of infancy. ${ }^{9}$

Although the prevalence of delayed linear growth has gone down in recent years, according to national and local surveys in developing countries, there are still significant contingents of stunted children under five years of age. ${ }^{4}$ In Brazil, despite the positive long-term trend in all regions and in for all socio-economic strata, there is still a gap between the poorest third of the population compared to those who have adequate living conditions. ${ }^{12}$

A comparison of the national data obtained by the 1989 National Survey of Health and Nutrition (NSHN) with those of the 1974 National Family Spending Study, show that the difference in terms of stature between Brazilian children and adolescents and those from North America has decreased for all ages. Nevertheless, $14.4 \%$ of the population aged between 0 and 10 years still have a lower height for age than the reference of population. Among the poorest third of the population there an even greater deviation from the Standard distribution, children with a stature deficit in relation to age clearly coming from the families with the lowest incomes. ${ }^{13}$

The NSHN data also show that the median for final height for Brazilian women corresponds to the average height for North American adolescents aged between 12 and 13 as evaluated in 1977. In the young adult population (20-25 years), the prevalence of stunting as a result of malnutrition, defined as a height of less than two Standard deviations from the average for the NCHS reference population, is $20.94 \%$ for males, and $19.63 \%$ for females, although this varies according to region, income bracket and between urban and rural areas. ${ }^{13}$

As for the long term tendency for growth in the adolescent population, it should be noted that, although the average height for Brazilian adolescents rose approximately $8 \mathrm{~cm}$ between 1975 and 1989, they are still around $10 \mathrm{~cm}$ shorter on average than their North American peers. ${ }^{14}$

Compared with the long-term growth trend in Japan, male adolescents of 14 years of age grew 7 cms between 1960 and 1975 compared with $4 \mathrm{~cm}$ among Brazilians of the same age between 1974 and 1989. In 18-year-old individuals, the gain in height of $3 \mathrm{~cm}$ corresponded to that observed at the beginning of the $20^{\text {th }}$ century in developed countries. Therefore, despite have achieved a better profile for the height of the Brazilian population, the results fall far short of those recorded in countries with a higher degree of social and economic equity over a similar time period. ${ }^{13}$

According to the National Population and Health Survey (NPHS), carried out in 1996, the prevalence 
of stunting (height for age $<-2 \mathrm{z}$ ) in children under five years of age, which had stood at $15.1 \%$ in 1989 , had gone down to $10.5 \%$. Despite this decrease, the prevalence was still around four times greater than that expected for the reference population distribution, and stunting continues to be the most significant deficiency for this age group. ${ }^{15}$

There is also concern with the fact that the deterioration of the Brazilian economy and the crystallization of an unequal distribution of income, especially in the 1980s and 90s, may, reflecting the health conditions of the population, suggest there may be at some stage a deceleration in the long-term positive growth trend for the country. Were this to be true, one of its effects would be to postpone for the distant future full development of genetic growth potential of important contingents of the country's population, especially in the North and Northeast regions and in the poorest third of the population. ${ }^{12}$

It can thus be argued that, despite the so-called long-term growth trend, stunting is still a major public health problem.

\section{Stunting and overweight: obesity or the effect of body proportions?}

Although endemic nutritional deficiencies are still to be found, the prevalence of weight deficit around the world has been gradually on the decline. ${ }^{4}$ In Brazil, the results of the NSHN, for 1989, already showed that, despite the high percentage of the population aged between 0 and 10 years with a height/age index below that of the reference distribution, the weight/height index was more or less equal to the reference. ${ }^{13}$ The results of the NPHS, carried out in 1996, confirm this, showing that, in children under five years of age, while the prevalence of stunting (height/age $<-2 \mathrm{z}$ scores) stood at $10.5 \%$, the weight for height deficit (weight/height $<-2 \mathrm{z}$ scores) showed a prevalence of only $2.3 \% .^{15}$

For many authors, these data are startling, and demonstrate the need to understand the nutritional status, or stature deficit concomitant to adequate or even greater than expected weight for height. ${ }^{16-23}$

A study with female adolescents living in slums in the municipality of São Paulo, showed that $21 \%$ had stunting associated with overweight. Of those who had stunting and overweight, $86 \%$ had a per capita income of less than one Brazilian minimum wage. The author states that, given the low income evidenced by the study, it is difficult to image that a wide range of foodstuffs would be available to cause overweight or obesity in adolescents, suggesting that the two situations, when associated with low stature, must have an etiology different from that described for conditions where stunting is not present. ${ }^{16}$

Another study of adolescents living on slums, restricted to males, detected that $26.3 \%$ were stunted, and that in $24 \%$ of cases there was an association with overweight. Among adolescents with normal height, the prevalence of overweight was around $8.6 \%$. The author suggests that this result may somehow reflect organic adaptation to malnutrition. ${ }^{17}$

Seeking an explanation for this supposed adaptation in possible alterations to the metabolism, Grillo et al. ${ }^{18}$ studied the resting metabolic rate (RMR) in female pre-pubescent and eutrophic schoolchildren who were stunted and normal height. They found that the former had a higher RMR. This metabolic profile, with a rise in the consumption of energy when resting, was considered by the authors to be typical of a pattern of malnutrition and does not therefore explain the occurrence of stunting associated with overweight.

In a study of female schoolchildren aged between 7 and 11 years, with and without stunting, an association was observed between the percentage of energy coming from fat and the weight gain for height only among the stunted girls. No differences were found between the two groups in terms of energy ingestion or the macronutrient composition of their diet. The authors aired the hypothesis that the high levels of overweight among the children who were malnourished could be, in part, due to greater susceptibility to weight gain as a result of high ingestion of fat. ${ }^{19}$

A study conducted by Trowbridge et al.,${ }^{20}$ in poor communities in Peru, evaluated children under five years of age with a height deficit for age and weight above that expected for their height. Taking into consideration nutritional and environmental factors affecting this population, the authors emphasize the need to take care not to underestimate malnutrition in populations where the weight for height appears to be adequate or greater than expected, despite high rates for child morbidity and mortality. Given that linear growth was shown to be retarded, it is also questionable whether the energy ingestion is sufficient to give rise to overweight. Having measured the quantity of water in the body and subcutaneous fat in these children, it was suggested that the weight for height greater than expected could not be attributed to obesity, as it was associated with a lower quantity of body fat, in addition to a greater quantity of lean tissue or greater hydration of this. 
Popkin et al. ${ }^{21}$ found in Brazil, a prevalence of $3.5 \%$ for overweight in children aged between three and six years of low stature, while, in South Africa, the percentage was $13.1 \%$, in China $17 \%$ and in Russia $48.6 \%$. Despite the lower prevalence of overweight in children of low stature in Brazil, even when adjusted for income, there was a significant association between low stature and overweight, differently from the other three countries studied. The authors question whether this is determined by the nutritional status, in apparently paradoxical fashion, given that the children evaluated did not have the opportunities, resources or lifestyle necessary for them to become obese.

Post \& Victora ${ }^{22}$ also find it difficult to explain how children with high levels of mortality and morbidity-living in dreadful socio-economic and environmental conditions and with high levels of height for age deficit-can have average weight for height measurements that are similar to if not above those of children in the developed world.

In an effort to explain this apparently paradoxical nutritional status, Post et al. ${ }^{23}$ took body measurements from stunted and non-stunted children and concluded that the low prevalence of weight for height deficit did not result from an excess of adipose tissue or muscle, but that there was a greater proportion between the trunk and the head and the shorter length of the legs among stunted children, compared with North American children, who were taken as the point of reference in terms of body measurements. For these authors, this situationwhich could be attributed to the slow rate of maturation of poor children-gives rise to a greater relation between weight and height because the head and the trunk contribute more to the overall body-weight.

Many studies focus simply on measuring the height of individuals and not on the components that make up this measurement. However, these components-the stature of the trunk and the head and the length of the legs-may differ during growth. The relations between the dimensions of specific segments of the body and of the body as a whole reflect precisely these differences in patterns of growth-which is called differential or allometric growth. Such an approach, provided by the analysis of body proportions indicators, have proved to be an important theoretical point on which to focus in interpreting the effects of nutritional deficits on body measurements. ${ }^{24-26}$

Santos \& Cabral-Filho, ${ }^{24}$ investigating the allometric relations between length of tibia and overall height in eutrophic and malnourished children aged between 6 and 30 months, found that, for this age group, malnourished children display a more pronounced reduction in the pace of growth in the tibia than for the body as a whole. For Wadsworth et $a l .,{ }^{27}$ the length of the legs is a more sensitive indicator of unfavorable socio-economic, dietary and environmental circumstances in children aged under five, as it is at this stage in life that the growth of this segment of the body is fastest.

This impairment of the body proportions and its effects on adequate weight for height are just some of the limitations on the use of the Body Mass Index (BMI) as an indicator for corporal adiposity. ${ }^{25}$ In groups with a high ratio between the length of body and the head and overall height, a reduction in the prevalence of overweight has been observed, especially among women, when the BMI is adjusted for the proportions of the body. ${ }^{26}$ Studies in adult populations who have possibly been exposed to malnutrition during growth have suggested that there is an association between low stature and overweight/obesity, as measured using the BMI, which could be caused by this effect of the body proportions. $^{28,29}$

\section{Stunting: the relations between global and localized adiposity and physio-pathological and clinical consequences}

In order to analyze better the validity of weight for height indices, such as the BMI, for a reliable diagnosis of obesity in populations with impaired stature and body proportions it is important to consider more direct measurements of the components that make it up, especially global and localized adiposity. Among the measures used to ascertain the quantity of body fat and its distribution are the thickness of the skinfold, which can be analyzed according to absolute values, the locality (central or peripheral) or included in equations for predicting the percentage of body fat, ${ }^{30}$ and the circumference of the body, the circumference of the waist and hip being those most commonly used.

In a sample of Colombian women with a mean height of $153 \mathrm{~cm}$, percentages for body fat and subcutaneous fat were found to be higher than in North American women of normal height. ${ }^{31}$

A longitudinal study in Senegalese adolescents showed a greater accumulation of subcutaneous fat in the upper part of the body (the trunk and arms) in those who were stunted, irrespective of the overall quantity of subcutaneous fat. According to these authors, there is as yet no precise explanation for this greater deposit of fat in the upper part of the body in 
stunted adolescents. However, it may be attributed to complex hormonal adjustments that occur with the onset of puberty and which could be affected by malnutrition. ${ }^{32}$

In a prospective study conducted in Jamaica with identified individuals aged between 9 and 24 months and accompanied between the ages of 7 and 11 years, the birth weight was found to be negatively associated with the ratio between the skinfolds below the shoulder blades and the triceps, as measured at 11 years of age. During the age interval under consideration, this ratio was the only variable that turned out to be higher in stunted individuals when compared to the controls. Given that other variables such as the percentage of body fat and isolated skinfolds of the shoulder blades and triceps turned out to be lower, these authors concluded that, for this age group, there is no evidence of a higher risk of adiposity and its consequences in individuals who had experienced retarded growth in early infancy. However, in relation to the finding for the distribution of body fat in these individuals, the most important result was the possibility of there being a predictive topographic accumulation of fat in future life, drawing attention to the chance of the centralization of fat becoming more accentuated after puberty. ${ }^{33}$

A study of an adult population from São Paulo, showed that, among women, there was a significant negative association between height and the ratio between the circumferences of the waist and the hips (WHR), even when adjusted for level of physical activity, income of head of household, marital status, level of schooling and smoking. ${ }^{28}$

A representative study of the city of Rio de Janeiro also found an increased risk of abdominal obesity (measured by WHR) in women of low stature, when controlled for race, socio-economic conditions and energy ingestion. ${ }^{29}$

In Guatemala, a longitudinal study suggested that that there is an association between weight on birth and growth in infancy with the distribution of fat in adulthood. Children with a lower birth weight and those with stunting in infancy showed higher WHR as adults, this being greater the lower the birth weight and when stature normalized at three years of age. $^{34}$

A cohort of Finnish children accompanied from birth to the end of adolescence showed that there is a need to investigate the effects on health of different biotypes at birth, as heavy newborns may have a greater risk of being overweight in the future, while low weight newborns may develop posterior abdominal obesity. ${ }^{35}$
There are strong indications, therefore, that the possible effects of retarded growth on the distribution of body fat may be linked both to the period of fetal growth and to post-natal growth, and it is worth noting further that birth weight correlates positively with height in infancy ${ }^{35,36}$ and adulthood. ${ }^{37,38}$

In a prospective study conducted in Jamaica, birth weight was controlled to ascertain whether the association between stunting and centralization of body fat remained significant. ${ }^{33}$ This adjustment made it possible to show that the birth weight is largely responsible for the differences in distribution of fat among individuals with or without stunting, although the results also suggested that growth retardation in infancy also had an effect.

Another longitudinal study carried out in the United Kingdom ${ }^{39}$ showed that, in adulthood, whatever the BMI, individuals who had delayed growth in infancy had a larger WHR. This study also adjusted for the relation with birth weight, suggesting a link between growth in infancy and WHR, irrespective of fetal growth.

Also worthy of attention in this British study is the fact that the occurrence was observed among females of a negative association between birth weight and WHR, which disappears when only the circumference of the waist is taken into account. This finding is relevant because it casts doubt on what is believed to be the greatest risk for abdominal obesity in women of low stature, as the association with the WHR could be attributed to a diminished hip circumference.

A longitudinal study of Senegalese adolescent girls, ${ }^{32}$ although it did not use the WHR, also raised this question, by showing that girls of low stature have a bi-iliac diameter shorter than that of girls of normal stature.

Although it is studied less than the circumference of the waist and abdominal fat, the circumference of the hips or pelvic-femoral adiposity has been the subject of some intriguing investigations. In a study associating body fat with the presence of cardiovascular risk factors in obese adolescents, the adipose tissue in the hips, measured using magnetic resonance, was shown to be inversely related to the concentration in serum of triacylglycerols and LDLcholesterol. According to these authors, this finding suggests the potentially protective effect of adipose tissue located in this region. ${ }^{40}$ Studies of adult men and women have produced similar findings. ${ }^{41,42}$

Likewise, analysis of the association between body circumferences and chronic diseases in US women taking part in a national survey carried out in 1969 , suggested that the adipose tissue in the hips 
plays this role. It was shown that in women of equal weight, relative to height and waist circumference, those with broader hips presented a significantly lower prevalence of hypertension, diabetes and vesicular biliar disease, as well as for menstrual abnormalities. ${ }^{43}$

Using a similar line of analysis, Seidell et al. ${ }^{44}$ report that narrow hips and a broad waist contribute independently to increased risk of type 2 diabetes. Thus, individuals with identical figures for the circumference of the waist may have a greater risk for this disease if their hips are slimmer. In women, the combination of a broad waist and slender hips was especially significant. In men, slimmer hips, independent of the size of the waist, were an important predictor of diabetes. ${ }^{44}$

The study carried out with women from São Paulo, although it analyzed only the WHR and circumference of the waist, suggests that this possible effect of the hips by showing that women of low stature (under the NCHS fifth percentile)-who had a greater chance of higher WHR, without the presence of high figure for waist circumference-had significantly higher concentrations of glucose and lipids in their serum when compared this those of normal height. ${ }^{28}$

Although it is not known to what extent low stature in the adult population is determined by deficiencies earlier in life nor what the exact mechanism is that determines its possible association with the topography of body fat, there is evidence that there is a link between fetal and post-natal growth and chronic non-communicable diseases. ${ }^{45-47}$ It would appear that, although those born with a higher than normal weight are more prone to become overweight that those with a low birth weight, the least desirable effects on health occur when a child born with a low weight becomes an obese adult. ${ }^{36,48,49}$

Specialists in this area $^{21}$ have asked why researchers have not shown, in other periods of history, when there were relatively high rates for low stature, the supposed role of this as a risk factor for obesity and chronic non-communicable diseases. The most logical reason, according to these scholars, would appear to be that the socio-economic circumstances that give rise to high prevalence of stature deficit did not furnish the opportunity for obesity to emerge as a public health problem. Although malnutrition in early life does in fact produce a predisposition towards obesity and its complications, it is only in the context of the epidemiological and nutritional transition that this predisposition has been able to manifest itself. ${ }^{21}$

Authors who have undertaken prospective studies of Jamaican individuals exposed to malnutrition in the first years of life-apart from also suggesting that the association between delayed growth and later overweight appears to depend on environmental factors, such as changes in the availability of food-consider the possibility that obesity and its consequences manifested themselves in the population under study during puberty or adulthood. ${ }^{33}$

Evidence suggests, therefore, that, owing to the greater quantities of abdominal adiposity and all the proven health implications of this, ${ }^{40,50}$ or the low degree of pelvic-femoral adiposity and the consequent deprivation of the supposed protective effect of this ${ }^{40-44}$ individuals with low stature, especially females, run a greater risk of being afflicted by chronic non-communicable diseases and need to be treated and receive special preventive care.

\section{Final remarks}

The results presented here, although they only can only be used as the basis for hypotheses, may have far-reaching repercussions for developing countries. As stature deficit in the early years of life is still a public health problem in these countries, the findings may have long-term implications so far as the occurrence of co-morbidities associated with overweight, obesity and the topography of corporal fat are concerned, especially considering the changes in diet and lifestyle that are also being observed in these regions.

\section{Acknowledgments}

We would like to thank the Co-coordinating Body for the Further Training of Higher Education Staff (CAPES), for the Masters grant awarded to make this research possible. 


\section{Referências}

1. WHO (World Health Organization). Physical status: the use and interpretation of anthropometry: report of a WHO Expert Committee. Geneva; 1995. (WHO Technical Report Series, 854).

2. Tanner JM. Growth as a monitor of a nutritional status. Proc Nutr Soc. 1976; 35: 315-22

3. Waterlow JC. Nutrición y crecimiento. In: Waterlow JC, organizador. Malnutrición proteico-energética. Washington, DC: OPS; 1996. p. 230-59. (Publicación Cientifica n. 555).

4. Frongillo Jr EA. Prevalências mundial e regional da má nutrição na infância. Anais Nestlé. 2001; 61: 1-10.

5. Kukzmarski RJ, Ogden CL, Grummer-Strawn LM. CDC growth charts: United States. Hyattsville, MD: National Center for Health Statistics; 2000. (Advanced Data from Vital and Health Statistics n. 314).

6. Frongillo EAJr. Introduction. J Nutr. 1999; 129: S529.

7. Stephensen CB. Burden of infection on growth failure. J Nutr. 1999; 129: S534-S8.

8. Ramkrishman U, Martorell R, Schroeder DG, Flores R. Role of intergenerational effects on linear growth. J Nutr. 1999; 129: S544-S9.

9. Martorell R, Riviera JA, Schroeder DG. Consecuencias a largo plazo del retardo en el crecimiento durante la niñez. Arch Latin Nutr. 1995; 45: 1109-35.

10. Chandra RK. Nutrition and immunity in serious illness. Proc Nutr Soc. 1993; 52: 77-84.

11. Black RE. Would control of childhood infections diseases reduce malnutrition? Acta Paediatr Scand. 1991; 374: 13340.

12. Monteiro CA, Benício MHDA, Gouveia NC. Evolução da altura dos brasileiros. In: Monteiro CA. Velhos e novos males da saúde no Brasil: evolução do país e de suas doenças. São Paulo: Hucitec; 1995. p. 126-40.

13. Brasil. Ministério da Saúde. INAN (Instituto Nacional de Alimentação e Nutrição). Pesquisa Nacional sobre Saúde e Nutrição: perfil de crescimento da população brasileira de 0 a 25 anos. Brasília, DF; 1990.

14. Sichieri R, Recine E, Everhart JE. Growth and body mass index of Brazilian ages 9 through 17 years. Obes Res. 1995; 3 (Suppl): S117-S21

15. Taddei JAAC. Desvios nutricionais em menores de cinco anos: evidências dos inquéritos antropométricos nacionais [tese livre-docência]. São Paulo: Escola Paulista de Medicina da Universidade Federal de São Paulo; 2000.

16. Sampei MA. Avaliação do estado nutricional e termogênese pós-prandial em adolescentes faveladas da região de Vila Mariana, município de São Paulo [dissertação mestrado]. São Paulo: Escola Paulista de Medicina da Universidade Federal de São Paulo; 1992.

17. Priore SE. Perfil nutricional de adolescentes residentes em favelas. São Carlos: Ed. Universidade Federal de São Carlos; 1996.
18. Grillo LP, Carvalho LR, Silva AC, Verreschi ITN, Sawaya AL. Influência das condições socioeconômicas nas alterações nutricionais e na taxa de metabolismo de repouso em crianças escolares moradoras em favelas no município de São Paulo. Rev Assoc Med Bras. 2000; 46: 7-14.

19. Sawaya AL, Grillo LP, Verreschi I, Da Silva AC, Roberts SB. Mild stunting is associated with high susceptibility to the effects of high fat diets: studies in a shantytown population in São Paulo, Brazil. J Nutr. 1998; 128 (Suppl): S415S20.

20. Trowbridge FL, Marks JS, Lopez de Romana G, Madrid S, Boutton TW, Klein PD. Body composition of Peruvian children with short stature and high weight-for-height. II. Implications for the interpretation for weight-for-height as an indicator of nutritional status. Am J Clin Nutr. 1987; 46: 411-8.

21. Popkin B, Richards MK, Monteiro CA. Stunting is associated with overweight in children of four nations that are undergoing the nutrition transition. J Nutr. 1996; 125: 300916.

22. Post CLA, Victora CG. The low prevalence of weight-forheight deficits in Brazilian children is related to body proportions. J Nutr. 2001; 131: 1290-6.

23. Post CLA, Victora, CG, Barros AJD. Baixa prevalência de deficit de peso para estatura: comparação de crianças brasileiras com e sem deficit estatural. Rev Saúde Pública. 1999; 33: 575-85.

24. Santos FRJB, Cabral-Filho JE. Desnutrição em crianças de 6 a 30 meses induz maior retardo de crescimento na tíbia do que no corpo. Rev IMIP. 1999; 13: 144-50.

25. Garn SM, Leonard WR, Hawthorne VM. Three limitations of the body mass index. Am J Clin Nutr. 1986; 44: 996-7.

26. Norgan NG, Jones PRM. The effect of standardizing the body mass index for relative sitting height. Int $\mathrm{J}$ Obes. 1995; 19: 206-8.

27. Wadsworth MEJ, Hardy RJ, Paul AA, Marshal SF, Cole TJ. Leg and trunk length at 43 years in relation to childhood health, diet and family circunstances; evidence from the 1946 national birth cohort. Int J Epidemiol. 2002; 31: 38390.

28. Velásquez-Meléndez G, Martins IS, Cervato AM, Fornés NS, Maruci MFN, Coelho LT. Relationship between stature, overweight and central obesity in the adult population in São Paulo, Brazil. Int J Obes. 1999; 23: 639-44.

29. Sichieri R, Siqueira KS, Moura AS. Obesity and abdominal fatness associated with under-nutrition early in life in a survey in Rio de Janeiro. Int J Obes. 2000; 24: 614-8.

30. Sigulem DM, Devincenzi UM, Lessa AC. Diagnóstico do estado nutricional da criança e do adolescente. J Pediatr. (Rio J) 2000; 76 (Supl 3): S275-S84.

31. Spurr GB, Reina JC, Shijiang L, Orozco B, Dufour DL. Body composition of Colombian women. Am J Clin Nutr. 1994; 60: 279-85. 
32. Bénéfice E, Garnier D, Simondon KB, Malina RM. Relationship between stunting in infancy and growth and fat distribution during adolescence in Senegalese girls. Eur J Clin Nutr. 2001; 55: 50-8.

33. Walker SP, Gaskin PS, Powell CA, Bennett FI. The effects of birth weight and postnatal linear growth retardation on body mass index, fatness and fat distribution in mid and late childhood. Pub Health Nutr. 2002; 5: 391-6.

34. Shroeder DG, Martorell R, Flores R. Infant and child growth and fatness and fat distribution in Guatemalans adults. Am J Epidemiol. 1999; 149: 177-85.

35. Pietiläinen KH, Kaprio J, Räsäinen M, Winter T, Rissanen A, Rose RJ. Tracking of body size from birth to late adolescence: contributions of birth length, birth weight, duration of gestation, parents' body size and twinship. Am J Epidemiol. 2001; 154: 21-9.

36. Hediger ML, Overpeck MD, Maurer KR. Growth of infants and young children born small of large for gestational age: findings from the Third National Health and Nutrition Examination Survey. Arch Pediatr Adolesc Med. 1998; 152: 1225-31.

37. Allison DB, Paultre F, Heymsfield SB. Is the intrauterine period really a critical period for development of adiposity? Int J Obes Relat Metab Disord. 1995; 19: 397-402.

38. Sorensen HT, Sabroe S, Rothman KJ. Birth weight and length as predictors for adult height. Am J Epidemiol. 1999; 149: 726-9.

39. Kuh D, Hardy R, Chaturvedi N, Wadsworth MEJ. Birth weight, childhood growth and abdominal obesity in adult life. Int J Obes. 2002; 26: 40-7.

40. Caprio S, Hyman LD, McCarthy S, Lange R, Bronson M, Tamborlane WV. Fat distribution and cardiovascular risk factors in obese adolescent girls: importance of the intraabdominal fat depot. Am J Clin Nutr. 1996; 64: 12-7.
41. Terry RB, Stefanick ML, Haskell WL, Wood PD. Contributions of regional tissue depots to plasma lipoprotein concentrations in overweight men and women: possible protective effects of thigh fat. Metabolism. 1991; 40: 33-40

42. Pouliot MC, Desprès JP, Nadeau A. Visceral obesity in men Diabetes. 1992; 41: 826-34.

43. Hartz AJ, Rupley DC, Rimm AA. The association of girth measurements with disease in 32856 women. Am J Epidemiol. 1984; 119: 71-80.

44. Seidell JC, Han TS, Feskens EJM, Lean MEJ. Narrow hips and broad waist circumference independently contribute to increased risk of non-insulin-dependent Diabetes Mellitus. J Int Med. 1997; 242: 401-6.

45. Dietz WH. Critical periods in childhood for development of obesity. Am J Clin Nutr. 1994; 59: 955-9.

46. Byberg L, McKeigue PM, Zethelius B, Lithel HO. Birth weight and the insulin resistance syndrome: association of low birth weight with truncal obesity and raisede plasminogen activator inhibitor-1 but not with abdominal obesity or plasma lipid disturbances. Diabetologia. 2000; 43: 54-60.

47. Gaskin PS, Walker SP, Forrester TE, Grantham-McGregor SM. Early linear growth retardation and later blood pressure. Eur J Clin Nutr. 2000; 54: 563-7.

48. Barker M, Robinson S, Osmond C. Birth weight and body fat distribution in adolescents girls. Arch Dis Child. 1997; 77: 381-3.

49. Shroeder DG, Martorell R. Fatness and body mass index from birth to young adulthood in a rural Guatemalan population. Am J Clin Nutr. 1999; 70: S137S-44.

50. Bjorntorp P. Abdominal fat distribution and disease: an overview of epidemiological data. Ann Med. 1992; 24: 15-8.

Submitted on July 13, 2006

Final version resubmitted on January 27, 2007

Aproved on March 16, 2007 